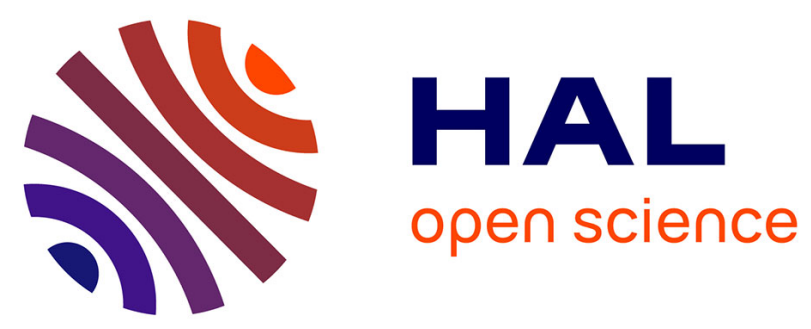

\title{
Divination, Fate Manipulation and Protective Knowledge In and Around" The Wedding of the Duke of Zhou and Peach Blossom Girl ", a Popular Myth of Late Imperial China
}

Vincent Durand-Dastès

\section{To cite this version:}

Vincent Durand-Dastès. Divination, Fate Manipulation and Protective Knowledge In and Around

"The Wedding of the Duke of Zhou and Peach Blossom Girl " , a Popular Myth of Late Imperial China. Michael Lackner. Coping with the future: theories and practices of divination in East Asia, Brill, 2017, Sinica Leidensia, 9789004346536. hal-01695407

\section{HAL Id: hal-01695407 https://hal.science/hal-01695407}

Submitted on 29 Jan 2018

HAL is a multi-disciplinary open access archive for the deposit and dissemination of scientific research documents, whether they are published or not. The documents may come from teaching and research institutions in France or abroad, or from public or private research centers.
L'archive ouverte pluridisciplinaire HAL, est destinée au dépôt et à la diffusion de documents scientifiques de niveau recherche, publiés ou non, émanant des établissements d'enseignement et de recherche français ou étrangers, des laboratoires publics ou privés. 


\title{
Divination, Fate Manipulation and Protective Knowledge In and Around "The Wedding of the Duke of Zhou and Peach Blossom Girl", a Popular Myth of Late Imperial China
}

\author{
Vincent Durand-Dastès
}

The story of the wedding of Peach blossom girl is a rather peculiar comic and magic narrative of late imperial China, first appearing at the end of the Yuan dynasty and afterwards continually retold and restaged. Its protagonist is a divine fortuneteller named Zhougong 周 公 (literally, “the Duke of Zhou") who goes down into the world to open a soothsayer shop. As his predictions never fail, the gods get worried that Zhougong may disclose too many heavenly secrets, and so they send against him a teenage girl, Peach Blossom (Taohua nü 桃 花女). An equally gifted diviner but also a magician, she allows several people doomed to die by Zhougong to escape with their life. Angered and humiliated, Zhougong decides to get rid of his young opponent in a rather original way: he asks her to marry into his household, but secretly uses beforehand all his divining science to choose the most inauspicious day and directions of space for the bridal cortege, hoping for Peach Blossom to fatefully perish. The girl, however, not only succeeds in avoiding the deadly trap, but she eventually further humiliates and defeats Zhougong. ${ }^{1}$

Before turning to the meaning of the tale, let us first dwell for a while on a weird detail in its publication history. In 1848, a vernacular novel (tongsu xiaoshuo 通俗小説) version of the story was published in sixteen chapters by a printer named Lianyi Tang 聯益堂 under the title Yinyang douyi shuo chuanqi 陰陽鬥異說傳奇 [Marvellous Tale of the Fight of Magic between Yin and Yang]. It contained two prefaces. One, anonymous and undated, comments briefly on the novel. The other, however, is strangely unrelated to the book's contents: signed by a scholar-official named Qiu Yuexiu 装曰修 of Xichang 西昌 (jinshi in 1739), it was originally a preface to a 1750 pediatric treatise by Chen Fuzheng 陈復正 (zi Feixia 飛 霞) titled Youyou jicheng 幼幼集成 [Complete Work on Children's Diseases] ${ }^{2}$. The presence of a preface to a medical treatise at the opening of a vernacular novel has puzzled

\footnotetext{
${ }^{1}$ See Taohua nü 桃花女.

${ }^{2}$ The book was first published in 1750 by the Dengyun Ge 登雲閣 in Guangdong. Chen Fuzheng, Youyou jicheng, 3.
} 
the few scholars who did comment on this book. Could this mean that Qiu Yuexiu was the author also of the novel? Or could it have been written by Chen Fuzheng himself ${ }^{3}$ ?

In this paper, I will neither verify nor reject such hypotheses relating to the Yinyang douyi shuo chuanqi's authorship. Instead, I shall take a different approach in trying to explain the curious co-existence of preface and novel. My own hypothesis is that some narratives concerned with fate and ways to influence it were considered so powerful that they became assimilated to texts preserving therapeutic or exorcistic knowledge. We'll come back to this point at the end of this essay.

\section{Divination and the vernacular narratives}

What can the Chinese vernacular novel of the Ming-Qing period tell us about the mantic arts of late Imperial China and, beyond that, about the Chinese conception of fate? In many respects, tongsu xiaoshuo narratives are fated stories: not only is karmic causality widely employed in the novels as a narrative device, but prophecies and stellar or dream divination frequently occur at important moments in the tales. Characters are physically depicted according to the principles of physiognomony, and many heroes are shown to have divinatory skills. $^{4}$

To take only one famous example, let us look briefly at what happened to the history of the Three Kingdoms (Sanguo 三國, 220-265 C.E.), the famous civil war that put an end to the glorious Han dynasty, when it was adapted to the format of a vernacular novel. As early as the Yuan Dynasty, the Sanguo zhi pinghua 三國志平話 [Story of the Records of the Three Kingdoms], one of the first examples of vernacular historical narrative retracing the Three Kingdoms war, had already injected an important amount of fated causality into the story, explaining the fall of the Han by means of the reincarnations of Han Xin 韓信, Peng Yue 彭 越, and Ying Bu 英布, the betrayed and murdered companions of the dynasty's founder, Liu Bang 劉幫. Divine justice allows them to return as Cao Cao 曹操, Liu Bei 劉備, and Sun Quan 孫權, the future rulers of the three kingdoms of Wei 魏, Shu 蜀, and $\mathrm{Wu}$ 吳, simply in order for them to take revenge by dismantling the glorious Han empire that they had helped

\footnotetext{
${ }^{3}$ As bibliographer Wang Guoliang states soberly, "[i]t should not have been put there without reason or cause" Kong fei wu yuan wu gu 恐非无缘无故; Wang Guoliang, "Yinyang douyi shuo chuanqi (yinyang dou) si juan shiliu hui," 493.

${ }^{4}$ On the mantic arts in Chinese ancient novels in general, see Wan Qingchuan, "Gudai xiaoshuo yu zhanbu shu."
} 
to found - while Liu Bang is to be reincarnated as the last, weak emperor of the dynasty, and thus obliged to witness in this role the end of his own great enterprise. ${ }^{5}$

One may also mention the portrayal in the later "Romance of the Three Kingdoms" (Sanguo zhi tongsu yanyi 三國志通俗演義) of the strategist Zhuge Liang 諸葛亮 as a diviner with supernatural foresight, a wise reader of heavenly signs, and, occasionally, a sorcerer who is able to manipulate fate.

\section{The diviner and his tutelary patrons}

Zhuge Liang is, of course, not the only tongsu xiaoshuo character to be depicted as performing divination or manipulating fate; in fact, there is hardly a wise strategist in historical novels who is not also a master of the magical and mantic arts. ${ }^{6}$ On a lesser level, here and there in vernacular novels, an ordinary diviner may be called on to explain an illness, to ensure the success of an adventurous enterprise, or to foretell the happy or unhappy outcome of an event. For example, in two roughly contemporary novels, written towards the end of the sixteenth century, we find scenes in which a diviner, before practising divination, invokes the blessings of the tutelary patrons of his art. The first appears in chapter 4 of Tieshu $j i$ 鐵樹記 [The Story of the Iron Tree], the vernacular hagiography of the Daoist immortal Xu Xun 許遜 (or 'Perfected lord' Xu zhenjun 許真君). A fortuneteller is called upon to predict the gender of the unborn baby of a rich man. The diviner claims to be a disciple of the Master of the Valley of Demons (Guiguzi 鬼谷子), and is nicknamed the “devil’s guess” (guitui 鬼 推). After lighting an incense stick, he begins to mutter the following incantation:

I bow respectfully in front of the gods of the Six ding, may the trigrams of King Wen bear a numinous answer! [...] If one asks with a sincere heart, the Trigrams shall be responsive! Burning carefully a stick of perfect incense, I pray respectfully to the patriarchs of the Eight Trigrams: Fuxi, Yu-the-Great, King Wen, the Duke of Zhou, Confucius: the five Great Saints!

The Seventy two sages guarding the Way of Confucianism; Master of the Valley of Demons; Master Sun Bin; Master Guan Lu; Master Yan Junping; Master Mu Xiu, Li Yan; the Divine generals of the Six ding and Six jia within the Trigrams; Thousand li Eye; Favourable Wind Ear; the boy who reports on the trigram; the lad who launches the trigram; all the divinities pacing the void; and the Magistrate of

\footnotetext{
${ }^{5}$ See Zhizhi xinkan quanxiang Pinghua Sanguo zhi juan shang, 373-374.

${ }^{6}$ See the chapter on the strategist in Ji Dejun 纪德君, Ming Qing lishi yanyi xiaoshuo yishu lun.
} 
the altar of the city walls of our prefectural province. May they all descend to inspect today's divination! $!^{7}$

虔叮六丁神, 文王卦有靈。( ...)人有誠心, 卦有靈感。謹焚真香, 虔請八卦祖師, 伏羲、大禹、 文王、周公、孔子, 五大聖人, 孔門衛道七十二賢、鬼谷先生、孙膑先生、管輅先生、嚴君平 先生、穆修李挺先生、卦中六丁六甲神將, 千里眼、順風耳, 報卦童子, 掷卦童郎, 虚空過往 一切神祗, 本省城隍社令, 咸望降臨, 鋻今卜筮。

The second extract is from Chapter 35 of the well-known masterwork Xiyou ji 西遊記 [The Journey to the West]. In a short scene, Monkey King Sun Wukong, yielding a calabash gourd, imagines playfully for a while that he is a diviner:

He shook the gourd, producing immediately a noise within. He said: "It is exactly like the sound of the tube used for divination! Let's do some divination so! I'll ask when my Master will be able to exit from this place, just see." He kept on waiving the gourd, muttering at the same time: "King Wen of the Zhouyi, Confucius the Saint, Master Peach Blossom girl, Master of the Valley of Demons!"8

他把那葫蘆摇摇, 一發響了。他道 : “這個象發課的筒子響, 倒好發課。等老孙發一課, 看師傅 什麼时時才得出門。”你看他手里不住的摇, 口里不住的念道 “周易文王、孔子聖人、桃花女先 生、鬼谷子先生。

Those two sequences, though differing in length and tone, follow the same pattern: before proceeding, a diviner invokes divinities to help him. We are provided with a small pantheon of the tutelary spirits of divination - according not to the literary tradition, but to the popular lore of the Ming period. Those divinities are of two kinds: some are remote beings, tutelary patrons of divination or diviners of ancient ages; others, only mentioned in the Iron Tree episode, are more familiar divinities, called upon to assist the actual divination about to take place. Among the latter, we find the local gods of the place, heavenly inspectors, the child gods whose responsibility it is to look at the trigrams that are to be used to read fate, or important figures such as the gods of the six ding and jia, a "set of spirits represent[ing] the animation of certain positions in the cycle of time" who may be summoned for prognosticatory as well as protective purposes. ${ }^{9}$ Some ritual texts explain how to dispatch

\footnotetext{
${ }^{7}$ Deng Zhimo, Tieshu ji, 481-482.

${ }^{8}$ Wu Cheng'en, Xiyou ji, 447-448.

${ }^{9}$ Campany, To Live, 73.
} 
those spirits on errands in order "to be informed of all matters under heaven." 10 There is little doubt, for instance, that Thousand li Eye and Favourable Wind Ear - the pair of martial guardians renowned respectively for their supernatural far-reaching sight and acute hearing who are called upon just after the six ding and jia - are to be used here in a similar role to that of divine spies.

Let us now turn to the tutelary figures summoned in both novels. First there are those taken from the group known as the "Nine sages” (jiusheng 九聖), They actually form something of a genealogy of sages, beginning with the "Three Emperors" (sanhuang 三皇) Fuxi 伏羲, Shennong 神農, and the Yellow emperor 黄帝, and continuing with the wise rulers Yao 堯 and Shun 舜, their successor Yu the Great 禹, the founders of the Zhou Dynasty, King Wen 文王 and the Duke of Zhou 周公, and, finally, Confucius 孔子. These tutelary figures of Chinese civilization are represented here because the "Nine Sages" have traditionally been associated with the gradual composition of the Yijing 易經 or Zhouyi 周易 [Book of Changes], the divinatory classic of the Zhou dynasty. Still, the first extract mentions only five of them - Fuxi, Yu-the-Great, King Wen, the Duke of Zhou, and Confucius - while the second lists only King Wen and Confucius. ${ }^{11}$

Next come the names of famous diviners of the past, among whom the only one to be mentioned in both extracts is Guigu zi 鬼谷子, the "Master of the Valley of Demons." This very shadowy figure of the Spring and Autumn period is said to have lived in seclusion in the place from which he took his sobriquet, and legend has it that he taught his disciple, Sun Bin 孫臏, the next name in the Iron Tree diviner's list, the art of strategy. He has been venerated at the popular level as the patriarch of physiognomy (xiangshu 相術) and is also associated with astrological methods of divination. ${ }^{12}$

Guan Lu 管輅 (209-256), the next figure mentioned in the Story of the Iron Tree extract, was a member of a group of diviners working for the Wei king, Cao Cao. Another diviner associated with physiognomy treatises, he is also the hero of a well-known medieval tale in which he saves a man who was fated to die young by telling him how to oblige the Northern and Southern polar stars so that they will grant him an extension of life. ${ }^{13}$ Yan

\footnotetext{
${ }^{10}$ Ge Hong, Baopuzi neipian j. 11; qtd. in ibid., 75.

${ }^{11}$ The chenwei 讖緯 tradition of prognosticary treatises even linked the "Nine Sages" with the composition of the diagrams associated with the Zhouyi, the "Yellow River Chart" (Hetu 河圖) and the "Luo River Writing" (Luoshu 洛書); see Zhong Zhaopeng, Chenwei lunlüe, 70-71.

${ }^{12}$ See Sakade Yoshinobu, "Guigu zi," 460-461; Kohn, “A textbook of physiognomony,” 256n6, respectively.

${ }^{13}$ See ibid., 234; Soushen ji, j. 3 搜神記卷三.
} 
Junping 嚴君平, a Han dynasty man, is reported to have refused to embark on an official career and led the life of a fortuneteller in Chengdu instead; he was a specialist on the Yijing. ${ }^{14}$ “Master Mu Xiu Li Yan” actually refers to two different men, Li Zhicai 李之才 ( $\mathrm{Zi}$ Yanzhi 挺之) and Mu Xiu 穆修, also specialists on the Yijing but in the Song period, who were involved in the transmission of the Wuji tu 無極圖 [Diagram of the Ultimateless] and Xiantian tu 先天圖 [Diagram of the Noumenal World $]^{15}$ from Chen Tuan 陳摶 to Shao Yong 邵雍, and thus are important figures in Neo-confucianism. ${ }^{16}$

\section{Holy patrons of divination in vernacular narratives}

Since, as I have pointed out earlier, these famous figures of the past constitute a kind of popular pantheon of holy diviners, it is unsurprising to find some of them appearing in the cast of characters of Ming-Qing novels or ballads. The Master of the Valley of Demons seems to have been particularly inspiring: he appears in many vernacular genres, from plays of the Yuan dynasty to tongsu xiaoshuo and modern folktales. For instance, the novel Sun Pang dou zhi yanyi 孫龐鬥智演義 [The Battle of Wits between Sun and Pang], printed in 1636 and also known as Qian Qi guo zhi 前七國志 [Former Annals of the Seven Kingdoms $],{ }^{17}$ tells how Sun Bin 孫臏 and Pang Juan 龐涓, originally friends, go to seek guidance in the supernatural and martial arts from the Master of the Valley of Demons in his mountain abode. When it turns out that Guigu zi favours Sun Bin, Pang Juan jealously destroys the heavenly books (tianshu 天書) given to Sun by Guigu zi and leaves. What follows is the well-known, long and pitiless fight between the two former friends. ${ }^{18}$ Pang Juan is eventually killed by Sun Bin, and the latter disappears from the world to return to his master in the Valley of Demons.

In this story, we find the theme of the celestial book as both a divinatory and military treatise (bingshu 兵書), whose possession allows its owner to become a divine strategist or even the founder of an empire. Another theme, one that is closely related to the tongsu xiaoshuo lore on divination, is the dangerous disclosure of heavenly secrets: Heaven will

\footnotetext{
${ }^{14}$ See Berkowitz, Patterns of Disengagement, 93-96.

${ }^{15}$ For those two terms, I follow here the english translations of Isabelle Robinet in her entry "Hetu and Luoshu", in Fabrizio Pregadio, ed. Encyclopedia of Taoism, vol. 1, 483-485.

${ }^{16}$ See Arrault, "Les diagrammes."

${ }^{17}$ A modern edition was published under the title Qian Hou Qi guo zhi.

${ }^{18}$ Already object of a splendid narrative by Sima Qian in the Records of the Grand Historian (Shi ji 史记).
} 
sometimes punish too brilliant diviners when they use their abilities to disclose facts that should have remained hidden. This theme appears in the Dong Yong 董永 story cycle, which, depending on the version, features in the role of the holy diviner either Sun Bin or Yan Junping, i.e., two of the characters who appear in the incantation of the Story of the Iron Tree. The story relates how the weaving maid, a celestial goddess, is married to the deserving Dong Yong in order to bear him a son. After that deed is done, she returns to Heaven, but, once grown up, the son - who in some versions of the story is none other than the philosopher Dong Zhongshu 董仲舒 - tries to find her. He is given a clue by Sun Bin (or Yan Junping): he has to await the moment where seven heavenly maidens will fly from the sky in the guise of birds to bathe in a pond, and then steal the feathered garment of the seventh: she is his mother. The young boy does as prescribed, but his mother, obliged to appear naked before her son, is enraged and decides to punish the fortuneteller for lightly disclosing her secret: she sends him a bottle concealing a magic fire that will eventually burn his heavenly book. ${ }^{19}$

\section{The Zhougong and Taohua nü cycle}

One also finds these two themes - the heavenly book given to or stolen by a mortal and the concern of Heaven to prevent secrets from being disclosed by too clever diviners - in the story which is the main subject of this paper, that of Zhougong and the Peach Blossom girl. Before finally turning to the core of the Zhougong-Taohua nü story, however, let me say a word concerning the cultural and literary background of its two main protagonists, both of whom appear in the diviner's incantation quoted above. One, Zhougong 周公, the "Duke of Zhou," ranks among the most illustrious figures of Chinese culture. The historical Duke of Zhou lived in the eleventh century B.C.E. and was the son of King Wen 文 and the brother of King $\mathrm{Wu}$ 武, the founders of the Zhou dynasty. He was especially revered by Confucius and became the incarnation of perfect government; having always refused to claim power for himself, he was ascribed a total lack of selfishness.

Among many other things, this Confucian saint has been linked to divination, especially in the later popular tradition. How was this connection established? As we have seen, Zhougong is counted among the "nine sages" involved in the composition of the Zhouyi,

\footnotetext{
${ }^{19}$ In some versions, the fire even blinds the unfortunate Yan Junping. The story is often quoted to explain why fortunetelling became so difficult and unreliable afterwards, or why diviners are often blind. On the various versions of this story, which appears first in the mid-sixteenth century short story collection Qingping shan tang huaben 青平山堂話本 [Vernacular Short Stories from the Clear and Peaceful Studio], see Idema, Filial Piety.
} 
as he is supposed to have authored the yaoci 爻受辛 sentences in it. But tradition also has him involved in the composition of another classic, the Zhouli 周禮 [Rites of Zhou], and he appears as a character in the calendrical and cosmological treatise Zhoubi suanjing 周髀算經 [The Gnomon of Zhou $]^{20}$ - although it is only in late medieval times that his name begins to be linked with divinatory treatises other than the Zhouyi. Among the Tang dynasty manuscripts found in the grotto-library of the Dunhuang monastery, for example, one counts several books claiming to transmit the mantic techniques invented by the Duke of Zhou:

\footnotetext{
Zhougong jiemeng 周公解梦 [Explanation of Dreams by the Duke of Zhou], a method of oneiromancy, or dream divination

Zhougong bufa 周公卜法 [Method of Divination of the Duke of Zhou], a treatise on cleromancy, or divination by casting lots

Zhougong wugu fa 周公五鼓法 [Method of the Five Drums of the Duke of Zhou], which belongs to the field of hemerology, i.e., the science of choosing auspicious and inauspicious moments in time

Zhougong Kongzi zhanfa 周公孔子占法 [Method of Divination of Confucius and the Duke of Zhou], a treatise on auguromancy, or bird divination ${ }^{21}$
}

While most of these texts were no longer transmitted after Tang times, the oneiromantic treatise enjoyed a long period of popularity, being printed and reprinted, with constant transformations, from Song times to the present day. ${ }^{22}$ Exactly why Zhougong was associated with mantic techniques has been the subject of conflicting interpretations. The theory of his alleged authorship of an extremely popular book on dream interpretation may originate from the fact that he was reputed to have written the oldest dream classification in the Chinese tradition, which figures in the Zhouli. ${ }^{23}$ But it may also have been influenced by the famous quote from the Analects of Confucius, where the aging sage complains that he is so old and rapipdly decaying that he no longer dreams of the Duke of Zhou. ${ }^{24}$ However, as far as the tongsu xiaoshuo is concerned, the link between Zhougong and divination rests mainly in his connection with the extremely important Yijing technique of trigram computation. As the early seventeenth century novel Han xiangzi zhuan 韓湘子傳 [The Story of Han Xiangzi]

\footnotetext{
${ }^{20}$ Cullen, "Chou pi suan ching," 33-38.

${ }^{21}$ On the different divination treatises claiming to transmit the techniques invented by Zhougong, see Kalinowski, Divination et société.

${ }^{22}$ Smith, Fortune Tellers and Philosophers, 252-253.

${ }^{23}$ Dièny, "Le Saint," 147n48.

${ }^{24}$ Lunyu 論語, “Shu er 述而,” 7-5. See Yang, Lunyu shizhu, 67. See Dièny, “Le saint.”
} 
beautifully expresses, Zhougong is close to being the very impersonation of Trigrams divination:

Some day, the great limit will be just above your head. Then, can your loving son or tender daughter replace you in death? Even with money, it is impossible to buy a medicine to combat impermanence. Even if you had the Venerable Lord Li's elixir, the face of the Buddha Śākyamuni, the literary skills of Confucius, the divinatory abilities of the Duke of Zhou [literally: "the yin, yang, and eight trigrams of the duke of Zhou"], the magical recipes of the famous physicians Bian Que and Cang Gong - each and every one of them has perished! $!^{25}$

有一日大限臨在你頭上, 那一個親的兒, 熱的女, 替得你無常? 有錢難買不死方, 有錢難買不 無常。你就有李老君的丹, 釋迦佛的相, 孔夫子的文章, 周公八卦陰陽, 盧醫扁鵲仙方, 他也 一個個身亡。

As to the Peach Blossom girl, although she likewise appears in the Xiyou ji's incantation among the tutelary figures of the mantic trade, she, of course, cannot match the grand figure of the Duke of Zhou, being a considerably less important character in the theater of Chinese culture. Besides, she is rooted not in the noble Confucian tradition, but in the popular realm of exorcism and eroticism: one of the first connotations of peach blossom is erotic, and as early as the Tao zhi yao yao 桃之夭天 poem of the Book of Odes, the blossoming peach tree heralds the time for love and weddings. From the sky, the Peach Blossom star (taohua xing 桃花星) influences human destiny by driving man and woman towards lust. And in the caves of the immortals, Peach Blossom fairies (taohua xian nü 桃花仙女) are the heroines of love encounters with wandering mortals. In chapter eight of the seventeenth century novel Guilian meng 歸蓮夢 [The Dream of the Return to the Lotus], for example, the male hero is led back towards the woman he loves through a dream encouter with an erotic female immortal called the Peach Blossom Goddess (taohua nüshen 桃花女神). ${ }^{26}$

The other connotation refers to the exorcistic virtues of peach tree wood - but most of the allusions to a "Peach Blossom girl" that we find in Ming-Qing novels seem to derive directly from her appearance as a powerful diviner and magician in the story of her conflict with Zhougong. To be sure, she is listed in chapter nine of the late Ming period novel Qi yao pingyao zhuan 七曜平妖傳 [The Quelling of the Sorcerers by the Seven Planets] alongside a group of well-known female magicians, such as Hu Yonger 胡永兒, the heroine of the earlier

\footnotetext{
${ }^{25}$ Yang Erzeng, The Story of Han Xiangzi, 231, with a few modifications.

${ }^{26}$ Gui lian meng, Shenyang, 93-95.
} 
novel San Sui pingyao zhuan 三遂平妖傳 [The Quelling of the Sorcerers by the Three Sui], female generals of the Yang family, or Liu Jinding 劉金錠, the magician-heroine of a cycle about the founder of the Song dynasty. In all other cases, however, she is mentioned together with Zhougong - either as his arch-enemy, as in the eighteenth-century Yesou puyan 野鼠曝 言 [A Country Codger's Words of Exposure], or, interestingly, as his complementary divine fortuneteller, as in the 33rd tale of the seventeenth century short story anthology Erke paian jingqi 二刻拍案驚奇 [Second Series of Amazing Tales].

Let us now turn to the story itself. Because it belongs basically to an oral cycle and figures prominently in performance genres, from “precious scrolls" (baojuan 賽卷) ballads to local operas, I choose to call it a "popular myth." However, it has surfaced twice in the print culture world of Late Imperial China: first in a Yuan dynasty zaju play, Taohua nü pofa jia Zhougong 桃花女破法嫁周公 [Peach Blossom Breaking the Magic Marries Zhougong], printed in the Ming period in the Yuan qu xuan 元曲選 [Selected Theatre Plays of YuanDynasty], ${ }^{27}$ and again in the already-mentioned tongsu xiaoshuo published in $1848 .{ }^{28}$ Aware of the dangers of attempting to characterize the Zhougong-Taohua nü story as a whole, which would indeed reveal many variations and contradictions, ${ }^{29} \mathrm{I}$ will focus here on the latter version of the story, the only one existing within the xiaoshuo format, that is, 1848's Taohua nü yin yang dou chuanqi 桃花女陰陽鬧傳 [Story of the Peach Blossom Girl's Fight of yin against yang], or Yinyang douyi shuo chuanqi 陰陽鬥異說傳奇 [Marvellous Tale of the Fight of Magic between yin and yang]. ${ }^{30}$

\footnotetext{
${ }^{27}$ The $z a j u$ play is generally attributed to Wang Ye 王曄, $z i$ Rihua 日华, a rather obscure playwright from fourteenth-century Hangzhou. There is also a version of the play among the sixteenth-century Maiwangguan 脉 望館 manuscripts, with some textual differences from the Yuan qu xuan version.

${ }^{28}$ On the history of the versions of the Zhougong-Taohu nü tale, the most comprehensive work of which I am aware is the master's thesis of Liu Huiping 劉惠萍, Taohua nü dou Zhougong gushi yanjiu.

${ }^{29}$ Neither of these two works, being rather crude in style, can be ranked among novels or dramas written by and for the literati. On the differences in tone and meaning among the great oral cycles, see Idema and Haiyan, Meng Jiangnü.

${ }^{30}$ The earliest edition dates from Daoguang 28 (1848). It seems to have originally been carved by a publisher named Lianyitang 聯益堂, whose priting blocks were then bought by a Cantonese publisher named Danguitang 丹桂堂. This original edition is kept by Beijing tushuguan and the British Library. The book was republished in 1866 and 1894, as well as in other undated late Qing editions. The Daoguang edition was photographically reproduced in the 1980s by Zhonghua shuju for its Guben xiaoshuo congkan 古本小説叢刊 [Collection of Ancient Editions of Novels] and the 1866 edition was included in the Shanghai guji chubanshe collection, Guben xiaoshuo jicheng 古本小説集成 [Compendium of Ancient Editions of Novels]. The 1894 edition has been republished in modern typography in the book Ming Qing shenhua xiaoshuo xuan 明清神話小説選 [Anthology of Mythological Novels of Ming and Qing Dynasties] (Zhejiang guji chubanshe, 1988) under the title Taohua nü 桃花女 [Peach Blossom Girl]. An electronic version is also available on the website Handian guji 漢典古籍
} 
Let me first present a summary of the story: During his ascesis on Mount Wudang 武 當, the god Zhenwu 真武 cuts open his own stomach in order to purify his bowels. Distracted by the extreme pain, he discards the sword he has used when he ascends to Heaven. The forgotten sword, whose contact with Zhenwu has enabled it to take human shape, ascends to Heaven too, where it becomes the lad keeping the trigram box of Lord Laozi 老子. One day, the boy escapes to descend to earth and is born into the family of a Shang 商 dynasty minister. Succeeding to his father's post, he becomes known by the name of Zhougong. Soon, dettered by the lack of virtue of the Shang king, he resigns from his high position at court and decides to lead the life of a simple fortuneteller. As, during his stay with Laozi, he has studied the Tiangang zhengjue 天罡正訣 [Secret Principles of the Stars of the tail of the Big Dipper], a heavenly book on divination and magic, Zhougong soon becomes a very famous diviner whose predictions never fail. But Heaven, worrying that he may thus disclose too many secrets of fate, sends against him a female immortal named the Peach Blossom girl. The girl is none other than the avatar of Zhenwu's sword sheath. She is born as the daughter of a benevolent old couple and, now a teenager, has never left the inner quarters of their home. The action takes a dramatic turn when she twice helps people whose imminent death Zhougong had predicted to escape with their lives. Not that the predictions were innacurate: the two man should indeed have died, but the Peach Blossom girl has taught them some white magic that permitted them to dodge their fate.

Troubled and angered at being challenged by a simple girl, Zhougong decides to get rid of this unexpected opponent in an unusal and cunning way. He asks her to marry his son, but the marriage plan is actually a deadly scheme: Zhougong has used all of his fortunetelling skills to choose the most dangerous time and place for a marriage. Having to travel through places under the deadly influence of the most baleful stars - "evil gods" (xiongshen 凶神), or “murderous stars” (shaxing 繁星) - Taohua nü is doomed to perish. However, the girl cleverly employs so much magic and so many rituals that, on the day of the wedding, she arrives safely at Zhougong's gate. She even succeeds in escaping the claws and teeth of the potent White Tiger star, waiting in ambush in the wedding chamber, and has him kill Zhougong's daughter instead. To add to his humiliation, Zhougong cannot but beg for the girl's mercy to bring his daughter back to life. Although he eventually succeeds in killing her by means of black magic, using a branch of the peach tree where her "basic fate" (benming 
本命) dwells, the poor diviner cannot prevent her organising her own resurrection. Unable to defeat each other, the two enemies then engage in such a terrible fight that it shakes heaven and earth - and attracts the attention of Zhenwu. The god recalls that the two enemies were originally his sword and sheath, stops their fight, and restores them to their place in his retinue of heavenly marshals.

\section{Duel of diviners, duel of magicians}

Both Zhougong and the Peach Blossom girl display brilliant divinatory skills in this story, but their mantic arts differ in both form and purpose. Zhougong, a former high official, has decided to become a diviner in order to provide guidance to the common folk. As he says at the beginning of his career:

\footnotetext{
Although unable to lead my sovereign back to the right ways and in no position to sacrifice my person for the sake of the country, can I spend my life as a mere commoner? Shouldn't I seize this occasion to resign and live in seclusion in the capital by seeking a quiet place to live? Couldn't I open a soothsayer shop to lead the people of my time? Be a leader in discussing the matters of Former Heaven, a chieftain in the analysis of the eight trigrams? Even if I cannot devote myself to my country and people, I'll be thus able to be remembered for many centuries: wouldn't that be fine?

我既不能匡君于正, 又不能舍身為國, 豈可同俗人一輩? 我何不趁此告职, 隐居在這朝歌, 尋 一個僻静之處。開一卜市引導世人? 作一個講先天的班頭, 剖八卦之領袖, 雖不能為國威民, 亦可流名萬載, 豈不是好 ${ }^{31}$
}

Unsurprisingly, when he begins his trade, Zhougong acts as a member of the elite. Although he will make a living out of it, his motivation in engaging in the mantic trade is also a moralistic and paternalistic one, and his tools will be those of a literatus: he sits sternly at a table covered with paper, ink, and brushes, and practices Yijing divination by selecting hexagrams from a trunk. Conversely, Taohua nü uses her body as a medium, counting fate on her fingers. As Richard Smith explains, in late imperial China, "popular mantic techniques included a rudimentary system of counting on finger joints," through which "even illiterates could determine the proper timing of a given enterprise" and which was "much in vogue

\footnotetext{
${ }^{31}$ Taohua nü, chapter 1, 224.
} 
among the common people. ${ }^{32}$ But there may be more to the Peach Blossom girl's exclusive use of finger counting: by stretching the fingers figures may be formed which can be not only a divinatory gesture but also have a direct magic efficiency. The hagiographic novel about the Fujian female deity Chen Jinggu 陳靖姑, for instance, shows how the goddess "by counting on her finger $[\ldots]$ transformed the room into a map of the bagua, the divination trigrams."33 As Brigitte Baptandier, who has studied the cult of this deity, observes, the hand constitutes in itself a diagram where the earthly branch and heavenly stems appear. It is used in astrology and in magic to calculate horoscopes and astral time. ${ }^{34}$ The divinatory gesture of the hands actually ressembles closely the mudrā that priests and exorcists draw on their fingers, with immediate efficiency. ${ }^{35}$ The use of this technique by the Peach Blossom girl demonstrates both her divinatory skill and her ability to go further: not only to read fate, but also to change it.

\section{The challenged order of fate}

Zhougong is not without his own ritual powers either. In several places in the novel, he bares his feet, undoes his hair, and, holding a sword, dances according to the pattern of the Northern Dipper constellation. This dance, in which one may easily recognize the wellknown “star pacing” (bugang 步罡) ritual, is widely performed by taoist priests and fashi 法 師 exorcists, but the Zhougong of our novel never employs it to act against fate. ${ }^{36}$ Let us take as an example the first time he performs bugang in the story: a couple of days before, he has predicted the imminent death of his assistant, Peng Jian 彭剪 - with sadness, but also without giving to the poor man the slightest hope of escaping his fate. It is only when he thinks that Peng Jian has died that he will perform the bugang exorcism near his unconscious body, and only to prevent the souls of his deceased aide from dispersing, thus permitting him to transmigrate into a good rebirth. When Peng Jian, not dead at all but only pretending to be asleep, suddenly rises, Zhougong at first thinks that he has seen a ghost. ${ }^{37}$ His shock is hardly surprising: Zhougong believes in the order of fate, and uses the exorcistic techniques that he

\footnotetext{
32 Smith, Fortune Tellers and Philosophers, 87, 185, 198. For a contemporary description of this mantic technique, see Homola, "Jeux de mains".

${ }^{33}$ Baptandier, The Lady of Linshui, 76.

${ }^{34}$ See ibid., 76 and $281 \mathrm{n} 6$.

${ }^{35}$ See Baptandier, "Les mudrā."

${ }^{36}$ On the fashi, see Davis, Society and the Supernatural .

${ }^{37}$ Taohua nü, chapter 9, 263.
} 
commands only modestly to bend destiny in the best direction. Taohua nü does the opposite: she can read the decrees of fate as well as Zhougong, but does not shy away from correcting, or even reversing, the order of destiny. She is said to be able to "break" (po 破) or "reverse" ( $f a n$ 反) the trigrams ( $g u a$ 卦) of Zhougong's divination, and, in order to do so, she resorts to rather transgressive methods.

In the episode just quoted, it is she, of course, who helps Peng Jian to escape his fate. She instructs Zhougong's assistant to hide in the temple of the three officers (Sanguan miao 三官廟) as in this very night, the seven stars of the Northern Dipper (Beidou xingjun 北斗星 君) are said to come and call out the names of those doomed to die shortly. As instructed by Taohua nü, Peng Jian prepares offerings for the gods, waves a golden chain, and chants an incantation. This ritual binds the star-gods and even gives them a bad headache, thus obliging them to fulfill Peng Jian's demands: he is given an extension of life by each of them, ending with a new promised lifespan of no less than 850 years; also, he will no longer be called Peng Jian, but henceforth be known as Pengzu 彭祖, the well-known Chinese Methuselah of ancient mythology. ${ }^{38}$

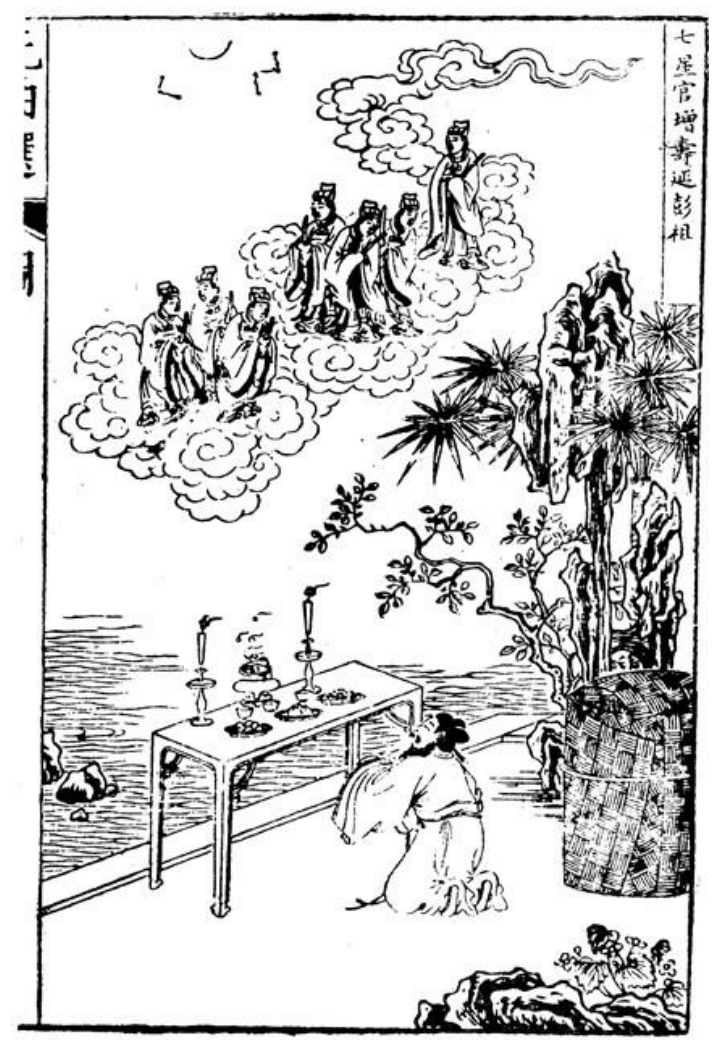

Peng praying the the seven stars of the Northern Dipper to extend his life (illustration for the zaju 雜劇 play, from the Yuan qu xuan 元曲選 version)

\footnotetext{
${ }^{38}$ Ibid., chapter 9, 262-263.
} 
Peng Jian's rescue is not the only one brought about by the Peach Blossom girl in the story: she will save from death or even restore to life no less than five people, including Zhougong and herself. She does so by using various techniques, most of which involve acts containing a touch of transgression or inversion: placing old, dirty garments on the threshold of a house (a place that should be kept clean and pure), constraining or blackmailing the gods, or using “counterflowing water" (niliu shui 逆流水), that is, water taken from a river pressed upstream by the mounting seatide.

\section{The Peach Blossom girl - a demonic champion of life?}

When confronted with the unexpected challenge posed to him by Taohua nü's actions, Zhougong uses two different methods. One, as we have seen, is to act as a diviner in a distorted way, selecting for the wedding ceremony the most lethal day, hour, and directions rather than the most propitious ones in order to ensure that the bride is killed instead of married. When that proves insufficient, ${ }^{39}$ he turns to another skill he possesses: exorcism.

To explain why and how he does that, we must turn to a component of Zhougong's character that I have so far only mentioned in passing. The Zhougong of the story, while drawing very clearly on the mythology of the Duke of Zhou as a patron of the mantic arts, is also modelled on another eminent figure: the god Zhenwu. Not only is Zhougong an incarnation of this god's weapon, but he also resembles him in many respects: from his first appearance in the human world, he is depicted as having a black face and a dark complexion - just like Zhenwu, the god of the northern parts of the sky, a direction associated with the colour black. As the story progresses, Zhougong acts less and less like a literati diviner, but is increasingly portrayed as a fashi exorcist: barefoot and bareheaded, wielding a sword. This is exactly the way in which Zhenwu, as one of the greatest exorcistic gods, is characterized in the iconography. And when Zhougong, failing to trap Taohua nü by arranging the deadly marriage, requires the aid of a powerful divinity, he chooses to call upon the "Black Killer," Heisha 黑繁, another god whose ritual role as well as features in the iconography are extremely close to those of Zhenwu. ${ }^{40}$

\footnotetext{
${ }^{39}$ To counter the danger of the unfortunate wedding, Peach Blossom "invents" a set of rituals which are actually part of the traditional wedding ceremony. The story serves to explain the origin of those rituals. I will not dwell on this question, because it is not directly connected to divination and has been analyzed in several Chinese articles on the Zhougong-Taohua nü story.

${ }^{40}$ Taohua nü, chapter 11, 275.
} 


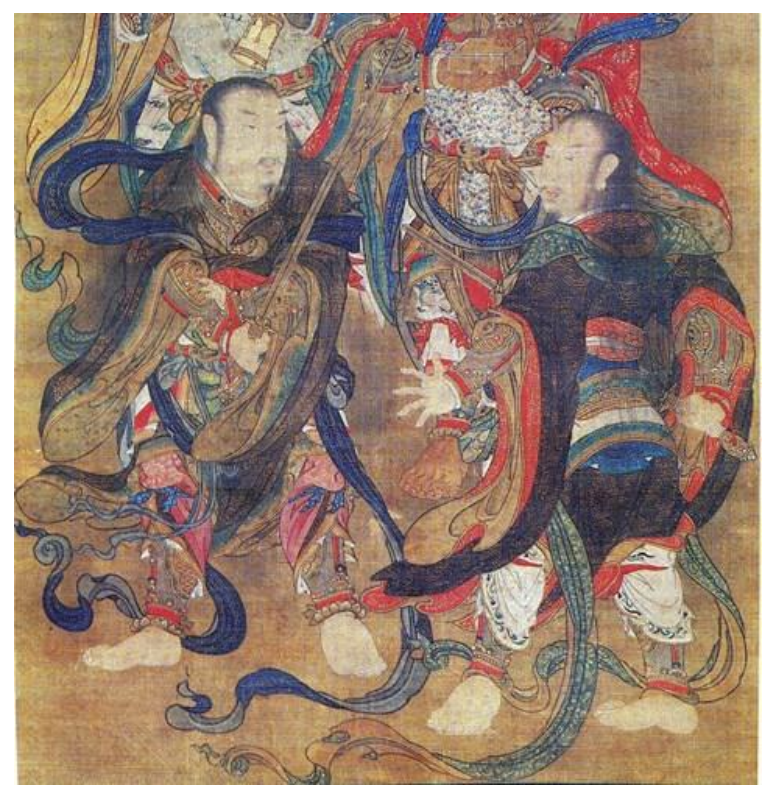

Heisha and Zhenwu pictured facing each other (Baoning si 寶寧寺 shuilu 水陸 painting, $15^{\text {th }}$ century)

In Chinese religion, a fashi exorcist may call upon a powerful martial god for a single purpose only: to get rid of a demonic being. Does this imply that the Peach Blossom girl could be such a being? Sure enough, Taohua nü is the heroine of this tale (while poor Zhougong appears in turn as a villain or a fool), but hints of her unorthodox, unruly nature, linked to her femininity, are also quite apparent. When Zhougong first tries to identify his opponent using his divinatory skills, he is warned that yin 陰 forces are dominating and that he will have to defeat a yinren 陰人, a term which refers to a female being, but also to a dangerous, malevolent creature. ${ }^{41}$ An even more signifiant episode, later in the story, shows Taohua nü summoning her own heavenly champion to resist Zhougong's attack: she has a being called Hongsha 紅鞄, the "Red Killer," descend from the sky. This Red Killer, as the chromatic antithesis of the Black Killer, will actually neutralize the powerful exorcistic god: when confronting each other, the Black and the Red Killer decide to retreat to their heavenly abodes without fighting. ${ }^{42}$

Heisha is a well-known god, object of a cult since at least the Song dynasty, but the same cannot be said of Hongsha: no figure of this name appears among the gods of the Chinese pantheon. ${ }^{43}$ However, demonic beings called hongsha do appear in various circumstances; for instance, at weddings, where they represent the demonic forces

\footnotetext{
${ }^{41}$ Ibid., chapter 6, 249.

${ }^{42}$ Ibid., chapter 12, 278-281.

${ }^{43}$ On the cult of the Black Killer, see Davis, Society and the Supernatural in Song China, 67-86.
} 
threatening to destroy the smooth proceeding of the ceremony. This demonic force seems directly connected to a powerful and dangerous substance: the virginal blood soon to be shed. Quite a few of the rites performed at weddings are obviously designed to neutralize the evil forces of the "Red Killer" in order to ensure a happy outcome for the marriage.

It has long been noted that female blood, shed during menstruation, birth, or defloration, gives women in China both "power and pollution." ${ }^{, 44}$ What is remarkable about the Zhougong-Taohua nü story is the way in which this force is transformed, or almost sublimated, by the tale. Threatening and evil hongsha influences become the benevolent god Hongsha, lending a helpful hand to the very positive character of the Peach Blossom girl. And yet they also serve as a reminder of her less-than-innocuous nature: to fight successfully against the yang order of fate, one needs a benevolent demon, it seems, a powerful character, gathering all of the frightful forces of the yin. Only then can such a towering figure as the Zhougong of the novel, modelled half on the highest Confucian Saint and half on one of the most powerful Taoist gods, be defeated. In other words, only a transgressive force can carry a rebellious spirit against the decree of fate.

Perhaps it is advisable to recall here the Xiyou ji episode from earlier, where Sun Wukong imagines for a while that he is a diviner: having invoked the very orthodox King Wen and Confucius, the "diviner" Monkey King summons the Peach Blossom girl together with a diviner whose name means litteraly, not meaninglessly I believe, the Master of the Valleys of Demons. Isn't it possible to detect here a discrete reminder of Taohua nü's unorthodox, almost demonic nature? She and Sun Wukong - himself a problematic figure, a former demonic character now enrolled as a heavenly protector - appear to be kindred spirits.

\section{A tale for extending longevity}

Exactly like the masterwork Journey to the West (Xiyou ji), the plays, ballads and novels that relate the story of Zhougong and Taohua nü are comedies: the way in which they depict a teenage girl poking fun at the prestigious name of the Duke of Zhou is indeed funny, and the brilliant story of the deadly fight taking the shape of a wedding is full of carnivalesque fantasy. But, again like the in the Journey to the West, the comedy is not without religious seriousness. There are many indications that the story had a ritual function in late imperial

\footnotetext{
${ }^{44}$ See for example Ahern, "The Power." On the power of female blood, see also Despeux, Immortelles, 215-219; Despeux and Kohn, Women in Daoism, 20-21 195-196 \& 223-227,; and Cohen, "Magic and Female Pollution." On virginal blood pollution, see De Pee, Text as Practice, 168-174; and Liu Ruiming, "Hunli zhong de 'bisha' minsu tanxi."
} 
Chinese society: for example, the theme is widely present on "precious scrolls," 45 a type of ballad, which was a well-known medium for the transmission of religious tales and myths; and in the world of local theater, the story of Zhougong and the Peach Blossom girl was also frequently featured. Thus, in the Anhui province dramatic genre Huiju 徽劇, the Taohua nü story, closely following the plot of the novel I have analyzed, involved a large cast of "humans, gods, devils and buddhas." ${ }^{\text {" It }}$ was staged at night, beginning at sunset to be played until dawn: this kind of representation is typical of the "Yin plays" (yinxi 陰戯), a kind of ritual theater involving the exorcism of ghosts and the resolution of tensions relating to matters of life and death.

Interestingly, one of the two baojuan ballads about the story is entitled Yanshou baojuan 延壽寶卷 [The Precious Scroll of the Extension of Longevity]. This is what I believe the story is all about. In his fight against Taohua nü, Zhougong incarnates the order of fate, which can be read but cannot be changed. Like other clever diviners in vernacular literature, he basically has good intentions, but is in danger of being pursued by Heaven because he may leak secrets that ordinary humans should ignore. The Peach Blossom girl is initially sent by Heaven precisely to belie Zhougong's too perfect predictions but, paradoxically, in doing so, she will have to disobey the very decrees of fate and act in a transgressive manner in order to save humans facing an impeding death. This topos is in no sense an invention of the anonymous authors of the Taohua nü legend. Very early in Chinese religious history, the quest for longevity or immortality has included a certain degree of transgression. Immortality can be achieved through moral acts and patient practice, but also by means of rebellious or deceiving acts. ${ }^{47}$ Taohua nü, as a yin being, a popular diviner but also a magician and sorceress, incarnates this very desire to extend the limits of one's allocated life span (ming 命).

\footnotetext{
${ }^{45}$ There seem to be two different baojuan about the Zhougong-Taohua nü story, namely numbers 1124 and 1125 of the Zhongguo baojuan zongmu 中國寶卷縱目 by Che Xilun 車錫倫, one with seventeen and the other with three extant manuscript copies.

46 Zhongguo xiqu zhi Anhui juan, 194.

${ }^{47}$ On these questions, see the excellent article by Ursula-Angelika Cedzich. See also Campany, "Living off the Books," 129-150.
} 

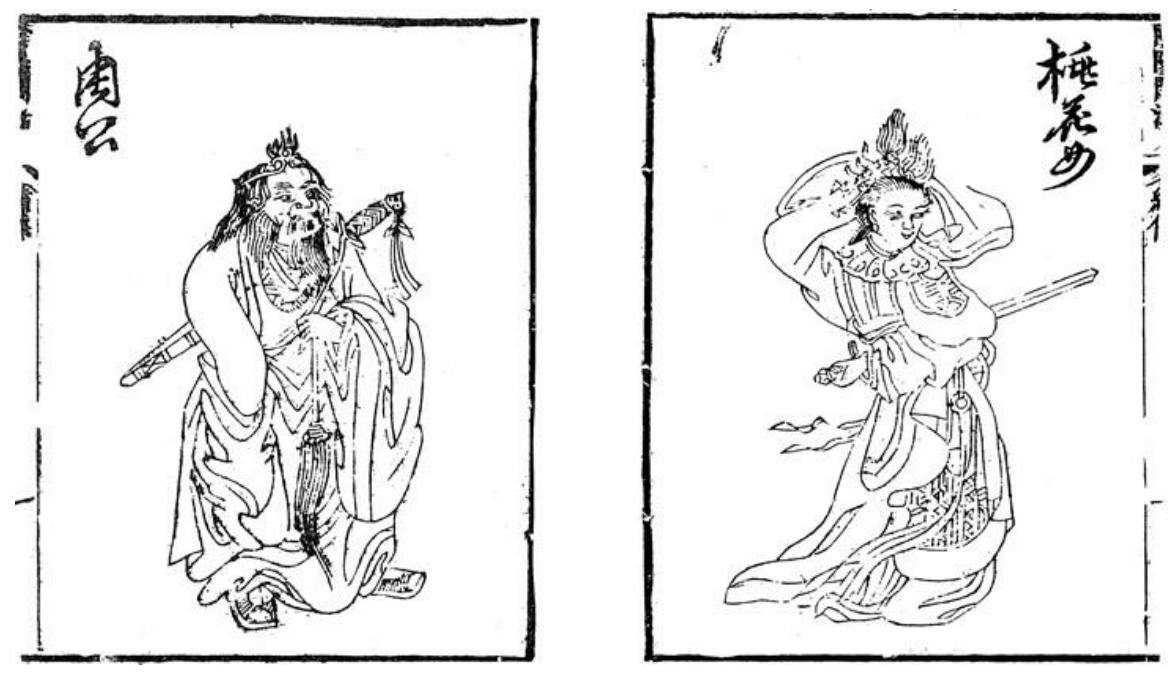

Zhougong and Taohua nü depicted as two magician-warriors. Woodgravings for the 1866 edition of the vernacular novel.

In the Taohua nü yin yang dou zhuan, the fight between the Peach Blossom girl and Zhougong fails to reach a conclusion: interrupted, they are summoned by Zhenwu and enrolled among his heavenly marshalls. This seems to be a rather late development in the Zhougong-taohua nü cycle, corresponding to the inclusion of the pair in the god's temple near the end of the Ming Dynasty ${ }^{48}$. By showing Zhougong and his young opponent take their places on each side of Zhenwu, as they are depicted in the temples of the exorcistic god, the story stresses the complementary nature of these two enemies. Also, in a way, their interrupted fight retains all of Zhenwu's potential power and energy. In the Xuejiawan 薛家 灣 village of Gansu 甘肃 province exists a community whose members practice the mantic and exorcistic arts as a traditional trade. They worship as their main tutelary god Zhenwu, whom they call their “infinite patriarch" (Wuliang zushi 無量祖師). Wuliang zushi is assisted by two other gods: one, “the patriarch of divination" (Suanming zushi 算命祖師), is Zhougong, and the other, known as "the patriarch of release from evil influences" (Yasheng $z u s h i$ 壓勝祖師), is the Peach Blossom girl. ${ }^{49}$ Depending on the type of practice they intend to perform, diagnostic divination or therapeutic exorcism, the religious specialists of Xuejiawan will call on the help of either the Duke of Zhou or the Peach Blossom girl.

\footnotetext{
${ }^{48}$ Grootaers, "The Hagiography," 144. In the zaju play, for example, the fight of the diviners and the marital confrontation were not yet so clearly linked with the mythology of Zhenwu.

49 “Xuejiawan ren de zhiye jiqi xinyang xisu 薛家灣人的職業及其信仰習俗," qtd. in Li Qiao, Hangye shen chongbai, 572-573.
} 
As Robert Campany has written about medieval China, "The whole point of ming was its ineluctability. The whole point of many esoteric and Daoist tenets and practices was to alter or circumvent ming nevertheless." 50 The late imperial popular myth of the fighting "wedding" of Zhougong and the Peach Blossom girl provides us with a delightful, picaresque illustration of this two-sided vision of fate: the two characters impersonate respectively yang and yin, sword and sheath, order and disorder, resignation and hope, fated death and rebellious quest for longevity. It confirms the existence of an ordered fate, as well as the evertempting possibility to subvert it.

\section{A life-extending myth and technical books}

Before concluding this short essay, let us recall the strange editorial feature we began with: couldn't it be possible that, by the Daoguang era, the story was considered such a prophylactic and therapeutic myth that it would seem proper for it to be opened by the preface of a medical treatise? This would be rather impossible to prove with certitude. However, another book of late Qing times may offer us a hint that it could indeed have been the case. The book is entitled Guxian Taohua nü Zhougong jianglun zhenshu 古賢桃花女周 公講論鎮書 [Exorcistic Book of the Debates between the Ancient Saints the Duke of Zhou and Peach Blossom Girl], but is also called in short Taohua zhen shu 桃花鎮書 [The Book of the Exorcism of Peach Blossom] (the term zhen 鎮 means literally "to repress, to contain," but is often used to designate techniques for dominating evil forces). It is by a man named Wang Dongshan 王東山 and undated, but library and auctions catalogs generally estimate that it was published during the Qing dynasty ${ }^{51}$

\footnotetext{
${ }^{50}$ Campany, "Living off the Books," 141.

${ }^{51}$ A short look on the web shows that the book is not a rarity: it is often proposed for sale on auction websites. In September 2007, for example, it was sold for the relatively modest sum of 8800 yuan; see http://pm.findart.com.cn/667849-pm.html.
} 


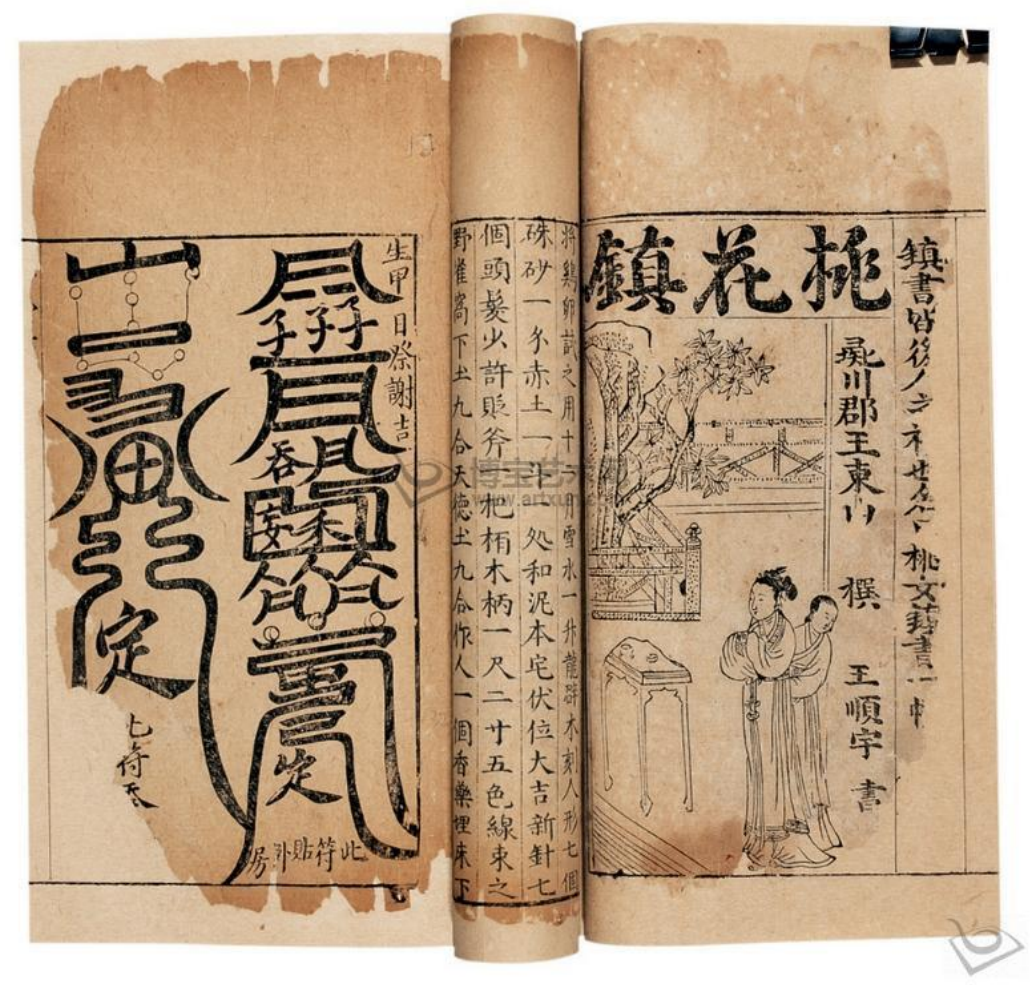

Taohua zhen shu 桃花鎮書

After recalling that "from the beginning of time, there has been first the women and only after the monarch, vassal, father and son, so among human relationships none is more important than marriage," 52 the book's preface goes on evoking the divinatory skill of Zhougong and the exorcistic power of Peach Blossom. Then it sums up briefly the story of their fight, explaining that it was only with the help of her book of exorcistic spells that Taohua nü could save her life. There are no longer narrative elements, however, in the body of the book itself: it consists of a collection of $f u$ 符 talismans with explanations for their use. ${ }^{53}$ The texts are devised to help solving obstacles or averting misfortunes related to marriage or marital life (first juan), or to ward away maternal death, death in infancy, or problems related to begetting offspring in general (second juan). Interestingly, the Beijing library's copy has been joined to two different short treatises which are also zhenshu 鎮書 aimed at different practical uses such as building houses or graves.

\footnotetext{
${ }^{52}$ Wang Dongshan, Guxian Taohua nü Zhougong jianglun zhenshu, 1a. The book was reprinted in 1917 by the Shanghai putong shuju 上海普通書局.

${ }^{53}$ For a short synthesis on the $f u$ talismans, Catherine Despeux, "Talismans and Diagrams."
} 
In a way, this little book presents us with a sort of inverted mirror image to the Qiu Yuexiu preface to the Daoguang edition of the Yinyang dou zhuan novel: while in the latter case, the preface to a pediatric treatise introduces the Peach Blossom story, in the Taohua zhen $s h u$ the evocation of this very tale introduces a collection of $f u$ talisman used for the protection of marital life and childbirth. Maybe this tiny piece of the history of a vernacular narrative, then, may help us to better understand the complex relationship between entertaining "fiction" (be it theater or vernacular novels) and ritual or technical knowledge in late imperial China. ${ }^{54}$

\section{Works Cited}

Ahern, Emily Martin. "The Power and Pollution of Chinese Women." In Women in Chinese Society, edited by Margery Wolf, and Roxane Witke, pp. 193-214. Stanford: Stanford University Press, 1975.

Arrault, Alain. "Les diagrammes de Shao Yong (1012-1077): qui les a vus?" Etudes Chinoises 19, no. 1-2 (2000): 67-112.

Baptandier, Brigitte. La Dame-du Bord-de-l'Eau. Nanterre: Société d'ethnologie, 1988.

-. The Lady of Linshui, a Chinese Female Cult. Stanford: Stanford University Press, 2008.

—. "Les mudrā du Lüshan pai, le battement de la vie." In Empreintes du tantrisme en Chine et en Asie orientale: imaginaires, rituels, influences, edited by Vincent Durand-Dastès. Bruxelles: Institut Belge des Hautes études chinoise, 2016: 139-157.

Berkowitz, Alan. Patterns of Disengagement: the Practice and Portrayal of Reclusion in Early Medieval China. Stanford: Stanford University Press, 2000.

Campany, Robert Ford. "Living off the Books: Fifty Ways to Dodge Ming 命 in Early Medieval China." In The Magnitude of Ming: Command, Allotment, and Fate in Chinese Culture, edited by Christopher Lupke, pp. 129-150. Honolulu: University of Hawai'i Press, 2005.

-. To Live as Long as Heaven and Earth: A Translation and Study of Ge Hong's Traditions of Divine Transcendents. Berkeley: University of California Press, 2002.

\footnotetext{
${ }^{54}$ For samples of recent debates on this relationship, see Meulenbeld, Civilized Demons, 266-367; and Johnson, Spectacle and Sacrifice, 145-175, 330-333. For a summary of previous debates, see my "Prodiges ambigus".
} 
Cedzich, Ursula-Angelika. "Corpse Deliverance, Substitute Bodies, Name Change, and Feigned Death: Aspects of Metamorphosis and Immortality in Early Medieval China.” Journal of Chinese Religion 29 (2001): 1-68.

Che Xilun 車錫倫. Zhongguo baojuan zongmu 中國寶卷縱目 [General Catalog of the Precious Scrolls]. Beijing: Yanshan, 2000.

Chen Fuzheng 陈復正 Youyou jicheng 幼幼集成 [Complete Work on Children's Diseases], Beijing: Renmin weisheng chubanshe, 1988.

Cohen, Paul A. "Magic and Female Pollution." In History in Three Keys: The Boxers as Event, Experience and Myth, edited by Paul A. Cohen, pp. 119-145. New York: Columbia University Press, 1997.

Cullen, Christopher. "Chou pi suan ching." In Early Chinese Texts: a Bibliographical guide, edited by Michael Loewe, pp. 33-38. Berkeley: The Society for the Study of Early China, 1993.

Davis, Edward L. Society and the Supernatural in Song China. Honolulu: University of Hawai'i Press, 2001.

De Pee, Christian. Text as Practice: The Writing of Weddings in Middle-Period China (Eighth through Fourteenth Centuries). Albany: State University of New York Press, 2007.

Deng Zhimo 鄧志謨. Tieshu ji 鐵樹記 [The Iron Tree]. In Mingdai xiaoshuo jikan 明代小说 辑刊 [Series of Novels of the Ming-Dynasty], edited by Hou Zhongyi 候忠义, vol. 1.4, pp. 797-927. Chengdu: Ba Shu shushe, 1993.

Despeux, Catherine. Immortelles de la Chine ancienne: Taö̈sme et alchimie féminine. Puiseaux: Pardès, 1990.

—. "Talismans and Diagrams." In Daoism Handbook, edited by Livia Kohn, pp. 498-540. Handbuch der Orientalistik 4. Leiden: Brill, 2000.

—, and Livia Kohn. Women in Daoism. Cambridge, MA: Three Pines Press, 2003.

Dièny, Jean-Pierre. "Le Saint ne rêve pas: de Zhuangzi à Michel Jouvet.” Etudes chinoises 20, no. 1-2 (2001): 127-199.

Durand-Dastès, Vincent, «Prodiges ambigus : les récits non-canoniques sur le surnaturel, entre histoire religieuse, histoire littéraire et anthropologie », Revue bibliographique de sinologie, $2002: 317-343$. 
Gan Bao 干寶; Wang Shaoying 汪紹楹 (ed.) Sou shen ji 搜神記, Beijing : Zhonghua shu ju 中華書局, 1979.

Grootaers, Willem A. "The Hagiography of the Chinese God Chen-wu (The Transmission of Rural Traditions in Chahar).” Folklore Studies 11, no. 2 (1952): 139-181.

Gui lian meng 歸蓮夢 [The Dream of the Return to the Lotus]. Shenyang: Chufeng wenyi chubanshe, 1987.

Homola, Stéphanie, « Jeux de main : les usages mnémotechniques de la main dans les calculs divinatoires en Chine contemporaine », Études chinoises vol. XXXIII-1 (2014-1), forthcoming.

Idema, Wilt. Filial Piety and its Divine Reward: The Legend of Dong Yong and the Weaving Maiden, with Related Texts. Indianapolis: Hackett, 2009.

-, and Lee Haiyan. Meng Jiangnü brings down the Great Wall: Ten Versions from a Chinese Legend. Seattle: University of Washington Press, 2005.

Ji Dejun 纪德君. Ming Qing lishi yanyi xiaoshuo yishu lun 明清歷史小説藝術論 [The Art of the Historical Novels of the Ming and Qing Dynasties]. Beijing: Beijing shifan daxue chubanshe, 2000.

Johnson, David. Spectacle and Sacrifice: the Ritual Foundations of Village Life in North China. Cambridge, MA: Harvard University Press, 2009.

Kalinowski, Marc, ed. Divination et société dans la Chine médiévale: étude des manuscrits de Dunhuang de la Bibliothèque nationale de France et de la British Library. Paris: Bibliothèque Nationale de France, 2003.

Kohn, Livia. "A Textbook of Physiognomy: The Tradition of the Shenxiang quanbian." Asian Folklore Studies 45, no. 2 (1986): 227-258.

Li Qiao 李橋. Hangye shen chongbai: Zhongguo minzhong zaoshen yundong yanjiu 行業神 崇拜中國民衆造神運動研究 [The Cult of the Crafts' Tutelary Gods: Studies on the Gods' Creation Processes among Chinese]. Beijing: Zhongguo Wenlian, 1999.

Liu Huiping 劉惠萍. “Taohua nü dou Zhougong gushi yanjiu 桃花女鬥周公故事研究 [Research on the Story of the Fight between Zhougong and Peach Blossom]." Master's thesis, 1992.

Liu Ruiming 劉瑞明. “Hunli zhong de 'bisha' minsu tanxi: jianlun chunühong jinji shiyuan 婚禮中的避鞄民俗探析一兼論處女紅禁忌始源 [Inquiries into the Customs for Avoiding Murderous Influences during Weddings: with a Study of the Origin of 
the Taboo about Virginal Blood]." Sichuan daxue xuebao - Zhexue shehuikexue ban 四川大學學報- 哲學社會科學版 [Sichuan University Journal - Philosophy and Social Sciences Issue] 141 (June 2005): 95-102.

Meulenbeld, Mark. "Civilized Demons: Ming Thunder Gods from Ritual to Literature." Ph.D. diss., Princeton University, 2006.

Qian Hou Qi guo zhi 前後七國志 [Former and Latter Annals of the Seven Kingdoms]. Changsha: Hunan renmin chubanshe, 1984.

Sakade Yoshinobu. "Guigu zi." In The Encyclopaedia of Taoism, edited by Fabrizio Pregadio, vol. 1, pp. 460-461. London: Routledge, 2008.

Smith, Richard J. Fortune Tellers and Philosophers: Divination in Traditional Chinese Society. Boulder, CO: Westwiew Press, 1991.

Taohua nü 桃花女 [Peach Blossom]. In Ming Qing shenhua xiaoshuo xuan 明清神話小説選 [Selection of Mythological Novels of the Ming and Qing Dynasties], edited by Zhang Ying 張穎, and Chen Su 陳速, pp. 217-301. Hangzhou: Zhejiang guji chubanshe, 1988.

Wan Qingchuan 萬晴川. “Gudai xiaoshuo yu zhanbu shu 古代小説與占卜术 [Ancient Novels and Mantic Techniques]." In Zhongguo gudai xiaoshuo yu fangshu wenhua 中 國古代小説與方術文化 [Ancient Chinese Novels and Magic Arts' Culture], edited by Wang Qingchuan, pp. 164-237. Beijing: Zhongguo Shehuikexue chubanshe, 2005, Wang Dongshan 王東山, Guxian Taohua nü Zhougong jianglun zhenshu 古賢桃花女周公講 論鎮書 [Exorcistic Book of the Debates between the Ancient Saints the Duke of Zhou and Peach Blossom Girl], corrected and printed (jiaozi 校梓) by the "Taoist dwelling in the rock of clouds” Yunju daoren 雲石居道人, no place, no date [Qing dynasty print].

Wang Guoliang 王國良. “Yinyang douyi shuo chuanqi (yinyang dou) si juan shiliu hui 陰陽 鬥異說傳奇(陰陽鬥)四卷十六回 [Novel about the Tale of the Fight of Magic between the Yin and the Yang, in Four Scrolls and Sixteen Chapters]." In Zhongguo gudai xiaoshuo zongmu baihua juan 中國古代小說總目白話卷 [General Bibliography of the Ancient Chinese Novels: Volume about Vernacular Novels], edited by Shi Changyu, p. 493. Taiyuan: Shanxi jiaoyu chubanshe, 2004.

$\mathrm{Wu}$ Cheng'en 吳承恩. Xiyou ji 西遊記 [The Journey to the West]. Beijing: Renmin wenxue, 1988. 
Yang Bojun 楊伯峻, Lunyu yizhu 論語譯注 [The Analects of Confucius, with translations and annotations], Beijing: Zhonghua shuju, 1980.

Yang Erzeng. The Story of Han Xiangzi: The Alchemical Adventures of a Daoist Immortal. Ca. 1600. Translated by Philip Clart. Seattle: University of Washington Press, 2007. Zhizhi xinkan quanxiang Pinghua Sanguo zhi 至治新刊全相平話三國志 [Plain Tale of the Annals of the Three Kingdoms, Newly Carved and Entirely Illustrated during the Zhizhi Era]. In Yuankan quanxiang pinghua wuzhong jiaozhu 元刊全相平話五種校 注 [Five Plain Tales Illustrated and Carved during the Yuan Dynasty, Edited and Annotated], edited by Zhong Zhaohua 鈡兆華, pp. 371-501. Chengdu: Ba Shu shushe, 1990.

Zhong Zhaopeng 钟肇鹏. Chenwei lunlüe 讖緯論略 [A Brief Discussion of the Chenwei Texts]. Shenyang: Liaoning jiaoyu chubanshe, 1991.

Zhongguo congshu zonglu 中國從書總錄 [General Bibliography of Chinese Collections]. 3 vols. Edited by Shanghai Library. Shanghai: Guji Chubanshe, 1986.

Zhongguo xiqu zhi Anhui juan 中國戲曲志安徽卷 [Annals of the Traditional Chinese Theatre: Anhui Province]. Beijing: Zhongguo ISBN zhongxin, 1993. 